\title{
The Effects of Filter Ventilation on Flavor Constituents in Cigarette Smoke*
}

\author{
by

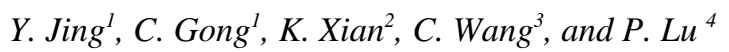 \\ ${ }^{1}$ College of Agronomy, Henan Agricultural University, Zhengzhou, P.R.China \\ ${ }^{2}$ Zhengzhou Tobacco Research Institute of CNTC, Zhengzhou, Henan, P.R. China \\ ${ }^{3}$ Burley Tobacco Experimental Station of CNTC, Wuhan, Hubei, P.R. China \\ ${ }^{4}$ Xinzheng Tobacco (Group) corporation of CNTC, Xinzheng, Henan, P.R. China
}

\section{SUMMARY}

The deliveries of 20 added flavor constituents, total particulate matter (TPM), nicotine, 'tar' carbon monoxide and water in cigarette mainstream smoke were studied when filter ventilation was $0,10 \%, 30 \%, 50 \%$ and $70 \%$, respectively. The flavor substance test was done by addition of standard samples. The flavor constituents in cigarette smoke condensate were separated by simultaneous distillation-extraction (SDE) and capillary gas chromatography (GC). The flavor constituents were identified and determined quantitatively by gas chromatography-mass spectrometry (GC-MS) and GC. The flavors studied were methylpyrazine, furaldehyde, 5-methylfuraldehyde, benzaldehyde, 6-methyl-5-hepten-2-one, trimethylpyrazine, 2acetylpyridine, phenylacetaldehyde, acetophenone, linalool, $\beta$-phenylethyl alcohol, isophorone, oxoisophorone, benzyl acetate, menthol, ethyl octanoate, $\beta$-damascenone, $\beta$ damascone, geranylacetone and $\beta$-ionone. The deliveries of TPM, nicotine, 'tar' carbon monoxide and water in mainstream smoke were determined according to International Standard methods. It was found that the flavor constituents and routine components in mainstream smoke decreased in different proportions as the filter ventilation increased. Carbon monoxide and 'tar' decreased more than nicotine. The flavor constituents with lower boiling points and lower molecular weights decreased more than those with higher boiling points and higher molecular weights. With the increase of filter ventilation, not only is the amount of smoke components reduced and the smoke taste weakened, but also the composition of smoke is modified and the quality of aroma changed slightly. These findings should be considered when developing low-'tar' cigarettes through the use of filter ventilation technology. [Beitr. Tabakforsch. Int. 21 (2005) 280-285]

\section{ZUSAMMENFASSUNG}

Die Freisetzung von 20 dem Tabak zugefügten Aromastoffen, die Gesamtpartikelmasse (TPM), Nikotin, Kondensat, Kohlenmonoxid und Wasser im Hauptstromrauch von Zigaretten wurden bei einer Filterventilation von jeweils 0\%, 10\%, 30\%, 50\% und 70\% untersucht. Die Analyse der Aromasubstanzen wurde unter Zugabe von Standardproben durchgeführt. Die Aromasubstanzen im Zigarettenrauchkondensat wurden durch simultane Destillation und Extraktion (SDE) und Kapillar-Gaschromatographie (GC) abgetrennt. Die Aromasubstanzen wurden mittels Gaschromatographie-Massenspektrometrie (GCMS) identifiziert und mittels GC quantifiziert. Bei den untersuchten Aromasubstanzen handelte es sich um Methylpyrazin, Furfural, 5-Methylfurfural, Benzaldehyd, 6-Methyl-5-hepten-2-on, Trimethylpyrazin, 2-Acetylpyridin, Phenylacetaldehyd, Acetophenon, Linalool, $\beta$-Phenylethylalkohol, Isophoron, Oxoisophoron, Benzylacetat, Menthol, Ethyloktanoate, $\beta$-Damascenon, $\beta$-Damascon, Geranylaceton und $\beta$-Ionon. Der Gehalt an TPM, Nikotin, Kondensat, Kohlenmonoxid und Wasser im Hauptstromrauch wurde gemäß ISO Methoden bestimmt. Es wurde gefunden, dass bei zunehmender Filterventilation die Aromasubstanzen und Referenzsubstanzen im Hauptstromrauch in unterschiedlichem Maße abnahmen. Der Kohlenmonoxid- und Kondensatgehalt war stärker verringert als der Nikotingehalt. Die Aromasubstanzen mit einem niedrigeren Siedepunkt und niedrigerem Molekulargewicht nahmen in höherem Maße ab als solche mit einem höheren Siedepunkt und höherem Molekulargewicht. Mit zunehmendem Filterventilationsgrad wurde nicht nur der Gehalt an Rauchkomponenten reduziert und der Geschmack des Rauches milder, sondern es veränderte sich auch die Zusammensetzung des Rauches und die Qualität des

*Received: $22^{\text {nd }}$ June $2004-$ accepted: $6^{\text {th }}$ January 2005 
Aromas. Diese Beobachtung sollte bei der Entwicklung von Zigaretten mit einem niedrigen Kondensatgehalt durch Filterventilationstechnik berücksichtigt werden. [Beitr. Tabakforsch. Int. 21 (2005) 280-285]

\section{RESUME}

Le rendement en 20 principaux composants aromatiques apportés au tabac, la matière particulaire totale (TPM), la nicotine, le goudron, le monoxyde de carbone et l'eau dans la fumée principale de cigarettes, ayant des différents taux de ventilation du filtre respectivement de $0 \%, 10 \%, 30 \%, 50 \%$ et $70 \%$, ont été analysés. L'analyse des composants aromatiques a été faite à l'aide des échantillons étalons. Les composants aromatiques présents dans le condensat de fumée de cigarette ont été séparés par distillation et extraction simultanée (SDE) et par chromatographie en phase gazeuse sur colonne capillaire (GC). Les composants ont été identifiés par chromatographie en phase gazeuse-spectrométrie de masse (GC-MS) et dosés quantitativement par GC. Les composants aromatiques étudiés étaient : méthylpyrazine, furaldéhyde, 5-méthylfuraldéhyde, benzaldéhyde, 6-methyl5-hepten-2-one, triméthylpyrazine, 2-acétylpyridine, phenylacétaldéhyde, acétophénone, linalool, $\beta$-phényléthylalcool, isophorone, oxoisophorone, benzylacétate, menthol, éthyl octanoate, $\beta$-damascénone, $\beta$-damascone, géranylacétone et $\beta$-ionone. Le rendement en TPM, nicotine, goudron, monoxyde de carbone et l'eau de la fumée principale ont été analysés avec des méthodes normalisées internationales. Il a été observé que les composants aromatiques et les échantillons étalons diminuent de façon différente en fonction du taux de ventilation. Le monoxyde de carbone et le goudron diminuent plus fortement que la nicotine. Les composants aromatiques ayant des points d'ébullition et des poids moléculaires plus faibles diminuent plus fortement que ceux ayant des points d'ébullition et des poids moléculaires plus élevés. Un taux plus important de ventilation du filtre ne conduit pas seulement à une réduction des rendements en composants et à un goût de la fumée plus faible, mais également à une modification de la chimie de la fumée et un léger changement de l'arôme. Ces résultats devraient être pris en considération lors du développement de cigarettes à faibles taux de goudrons en ayant recours à la technologie de la ventilation du filtre. [Beitr. Tabakforsch. Int. 21 (2005) 280-285]

\section{INTRODUCTION}

Aroma is one of the most important factors in evaluating tobacco and cigarette quality. It is important to analyze the flavor constituents of tobacco and cigarette smoke in order to improve their quality.

During the past several decades, many studies on flavor of tobacco were done (1-18). During the past two decades there has been rapid growth in the use of ventilated filter cigarette, which has led to extensive research to describe the relationship between filter ventilation and cigarette smoke deliveries (19-22). Research on effects of filter ventilation on flavor constituents in cigarette smoke is not as extensive (19). However research on some important aroma components in cigarette mainstream smoke at different filter ventilation levels has not been reported. The purpose of the current work was to study the effects of different filter ventilation levels on the deliveries of some important flavor constituents and routine components in mainstream smoke and thereby to obtain some data which might be helpful in the cigarette leaf blending, casing and flavoring.

Steam distillation and organic solvent extraction are the usual methods for separating flavor constituents. Now, the headspace-isolation method and simultaneous distillationextraction (SDE) method are also used. Because the SDE method (23) makes steam distillation and solvent extraction take place simultaneously, the operation is simple and rapid. In this study, the SDE method gas chromatography (GC) and gas chromatography-mass spectrometry (GC-MS) technology were used to quantify flavor constituents.

\section{MATERIALS AND METHODS}

\section{Materials}

Special 84-mm flue-cured cigarettes were prepared for this study. Different filter ventilation levels were made by laser beam perforation. The test samples were selected according to the following physical properties:

$\left.\begin{array}{lll}\text { Filter ventilation } & \text { Pressure drop } & \text { Weight } \\ \hline 0 \pm 1 \% & 932 \sim 1030 \mathrm{~Pa} \\ 10 \pm 1 \% & 883 \sim 981 \mathrm{~Pa} \\ 30 \pm 1 \% & 736 \sim 834 \mathrm{~Pa} \\ 50 \pm 1 \% & 588 \sim 686 \mathrm{~Pa} \\ 70 \pm 1 \% & 490 \sim 588 \mathrm{~Pa}\end{array}\right\} \begin{aligned} & \\ & \end{aligned}$

\section{Analysis procedure for the added flavor constituents}

There are many kinds of flavor substances in tobacco and cigarette smoke, but their amounts are very low. In our experiment, some standard flavoring substances were injected into test cigarettes. The amount of each flavor constituent injected was $400 \mu \mathrm{g}(25 \mu \mathrm{L} \times 16 \mu \mathrm{g} / \mu \mathrm{L})$ per cigarette. The 20 flavor constituents were then quantified in the mainstream smoke of the cigarettes (alcohol). These flavor constituents were as follow: methylpyrazine, furaldehyde, 5-methylfuraldehyde, benzaldehyde, 6-methyl-5hepten-2-one, trimethylpyrazine, 2-acetylpyridine, phenylacetaldehyde, acetophenone, linalool, $\beta$-phenylethyl alcohol, isophorone, oxoisophorone, benzyl acetate, menthol, ethyl octanoate, $\beta$-damascenone, $\beta$-damascone, geranylacetone and $\beta$-ionone. Figure 1 shows the entire process of treating cigarette samples. Figure 2 shows the simultaneous steam distillation-extraction apparatus used in the experiment.

The entire process of treating control cigarette samples was the same as shown in Figure 1 except that the control samples were not injected with the flavor solution.

Concentrated SDE solutions were quantified by GC and GC-MS. The 20 injected flavor constituents in cigarette smoke were determined at the five different filter ventilation levels according to the flavor constituents peak area difference between control samples and injected samples by the internal standard method. Phenylethyl acetate was used as internal standard (IS). 


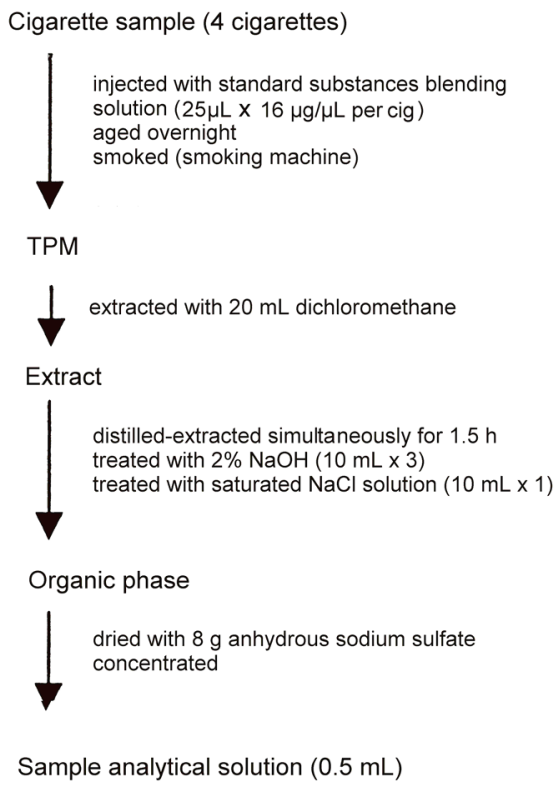

Figure 1. The process of treating cigarette samples

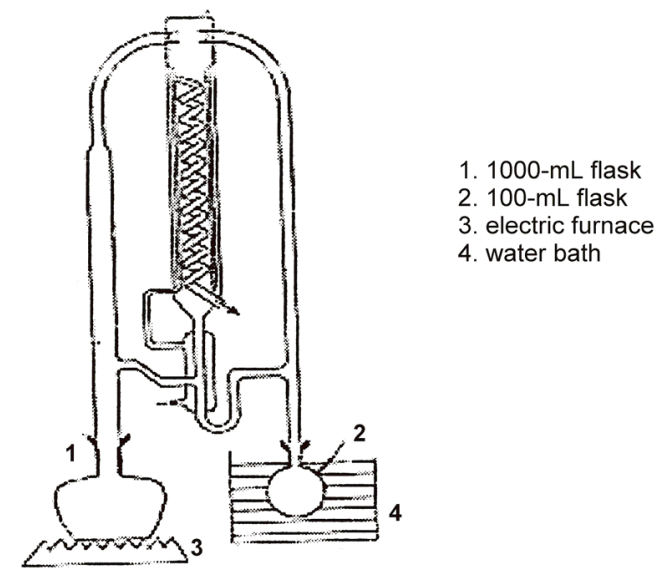

Figure 2. The SDE apparatus

GC (HP5890) conditions: Ultra 2, $50 \mathrm{~m} \times 2 \mathrm{~mm}$ i.d. $\times 0.33$ $\mu \mathrm{m}$; FID, injector and detector temperature, $280{ }^{\circ} \mathrm{C}$; programming temperature, $70{ }^{\circ} \mathrm{C} \rightarrow\left(4{ }^{\circ} \mathrm{C} / \mathrm{min}\right) \rightarrow 100{ }^{\circ} \mathrm{C} \rightarrow$ $\left(5{ }^{\circ} \mathrm{C} / \mathrm{min}\right) \rightarrow 170{ }^{\circ} \mathrm{C} \rightarrow\left(8{ }^{\circ} \mathrm{C} / \mathrm{min}\right) \rightarrow 260{ }^{\circ} \mathrm{C}$; split ratio, 54:1; carrier gas, $\mathrm{N}_{2}$.

GC-MS (HP5988) conditions: Ultra 2, $50 \mathrm{~m} \times 0.2 \mathrm{~mm}$ i.d. $\times 0.33 \mu \mathrm{m} ; \mathrm{FID}$, injector and detector temperature, $280^{\circ} \mathrm{C}$; programming temperature, $70{ }^{\circ} \mathrm{C} \rightarrow\left(4{ }^{\circ} \mathrm{C} / \mathrm{min}\right) \rightarrow 100{ }^{\circ} \mathrm{C} \rightarrow$ $\left(5{ }^{\circ} \mathrm{C} / \mathrm{min}\right) \rightarrow 170{ }^{\circ} \mathrm{C} \rightarrow\left(8{ }^{\circ} \mathrm{C} / \mathrm{min}\right) \rightarrow 260{ }^{\circ} \mathrm{C}$; ionization voltage, $70 \mathrm{ev}$.; carrier gas, He.

\section{Determination of routine smoke components}

The deliveries of TPM, nicotine, 'tar', carbon monoxide and water in cigarette mainstream smoke were determined according to the corresponding International Standard with a Filtrona SM400 smoking machine.

In addition, the organoleptic properties of cigarettes with different filter ventilation were evaluated by a smoking panel.
Table 1. Recovery of the 20 flavor constituents

\begin{tabular}{|c|c|c|}
\hline Compound & CAS RN & Recovery (\%) \\
\hline Methylpyrazine & $109-08-1$ & 77.9 \\
\hline Furaldehyde & $98-01-1$ & 78.4 \\
\hline 5-Methylfuraldehyde & $620-02-0$ & 84.8 \\
\hline Benzaldehyde & $100-52-7$ & 81.5 \\
\hline 6-Methyl-5-hepten-2-one & $110-93-0$ & 82.1 \\
\hline Trimethylpyrazine & $14667-55-1$ & 81.8 \\
\hline 2-Acetylpyridine & $1122-62-9$ & 75.8 \\
\hline Phenylacetaldehyde & $122-78-1$ & 65.6 \\
\hline Acetophenone & $98-86-2$ & 81.3 \\
\hline Linalool & $78-70-6$ & 83.2 \\
\hline$\beta$-Phenylethyl alcohol & $60-12-8$ & 33.5 \\
\hline Isophorone & $78-59-1$ & 83.9 \\
\hline Oxoisophorone & $1125-21-9$ & 80.8 \\
\hline Benzyl acetate & $140-11-4$ & 78.9 \\
\hline Menthol & $89-78-1$ & 54.2 \\
\hline Ethyl octanoate & $106-32-1$ & 84.3 \\
\hline$\beta$-Damascenone & $23696-85-7$ & 85.5 \\
\hline$\beta$-Damascone & $23726-92-3$ & 83.7 \\
\hline Geranylacetone & $3796-70-1$ & 85.8 \\
\hline$\beta$-Ionone & $14901-07-6$ & 82.4 \\
\hline
\end{tabular}

\section{RESULTS AND DISCUSSION}

\section{Selection of conditions for the SDE process}

The optimum temperature for the SDE water bath and the time for the SDE experiments were determined, i.e., whether or not the collected TPM was fully extracted. Through comparisons, it was determined that 60 was the optimum water bath temperature, $1.5 \mathrm{~h}$ was the proper time for the SDE.

\section{Recovery}

It is the recovery of SDE process. The determining process is as follows: First, I added the 20 flavor substances blending solution to the $1000-\mathrm{mL}$ flask before distilledextraction simultaneously. Then the following process is shown in the later part of Figure 1 (from distilled-extracted simultaneously to the end of the figure). Recovery $=$ the determining result amount/the added amount. The recovery of the method is listed in Table 1 . The recoveries of most flavor constituents determined are high.

\section{Repeatability}

Five groups of cigarette samples ( 0 filter ventilation cigarettes) were used to estimate the repeatability of the method. The results are shown in Table 2. The coefficient of variation for 19 of the 20 flavor constituents is below $10 \%$.

The effect of filter ventilation levels on deliveries of added flavor constituents in cigarette smoke

Figure 3 shows the gas chromatograms of the flavor constituents in mainstream smoke from 0 and $70 \%$ filter ventilation cigarette samples injected with the standard flavor solution. 
Table 2. Repeatability $(n=5)$

\begin{tabular}{|c|c|}
\hline Compound & Coefficient of variation (\%) \\
\hline Methylpyrazine & 5.70 \\
\hline Furaldehyde & 4.61 \\
\hline 5-Methylfuraldehyde & 5.25 \\
\hline Benzaldehyde & 5.03 \\
\hline 6-Methyl-5-hepten-2-one & 4.68 \\
\hline Trimethylpyrazine & 5.04 \\
\hline 2-Acetylpyridine & 5.50 \\
\hline Phenylacetaldehyde & 14.7 \\
\hline Acetophenone & 8.39 \\
\hline Linalool & 7.82 \\
\hline$\beta$-Phenylethyl alcohol & 6.53 \\
\hline Isophorone & 6.91 \\
\hline Oxoisophorone & 7.68 \\
\hline Benzyl acetate & 7.48 \\
\hline Menthol & 7.20 \\
\hline Ethyl octanoate & 8.57 \\
\hline$\beta$-Damascenone & 6.01 \\
\hline$\beta$-Damascone & 5.98 \\
\hline Geranylacetone & 5.92 \\
\hline$\beta$-Ionone & 4.91 \\
\hline
\end{tabular}

Table 3 shows the deliveries and reduction rates of the flavor constituents in mainstream smoke from the five different filter ventilation cigarette samples injected with the standard flavor solution.

Examination of Table 3 indicates that when the filter is not vented, the delivery rate of flavor constituents is less than $40 \%$ of the injected amount, i.e., column A.Q. is based on
$400 \mu \mathrm{g} / \mathrm{cigarette}$. At $34 \%$, menthol has the highest delivery rate. Nine of the delivery rates of flavor constituents are less than $10 \%$. The delivery rates of furaldehyde, benzaldehyde and phenylacetaldehyde are only $4 \%$. The delivery rates of alcohols and most of ketones are similar; ranging from 16 to $23 \%$, but some ketones are lower, e.g., 6-methyl-5-hepten-2-one has a delivery rate of only $5 \%$. The delivery rates of esters are approximately $10 \%$. The delivery rates of basic substances are lower, e.g., methylpyrazine has only $5 \%$ delivery rate.

As filter ventilation is increased, all of the 20 added flavor constituents in cigarette mainstream smoke are reduced, but not in the same proportion. The deliveries of different aroma components are different at different ventilation level and they are also different at the same ventilation level. With increased ventilation, the deliveries of components which are lower in unvented cigarette smoke are reduced more, such as methylpyrazine, furaldehyde, benzaldehyde and phenylacetaldehyde. The deliveries of components which are higher in unvented cigarette smoke are reduced less with increasing ventilation, e.g., menthol, $\beta$-damascenone, $\beta$-damascone, and $\beta$-ionone.

Examination of the boiling points and molecular weights of the flavor constituents reveals that flavor constituents of lower boiling point and lower molecular weight are more affected by the increase in ventilation. E.g., the reduction of methylpyrazine is $16 \%$ at $10 \%$ ventilation and $88 \%$ at $70 \%$ ventilation. The higher boiling point and higher molecular weight flavor constituents are affected less by the increased ventilation. E.g., $\beta$-damascenone, $\beta$-damascone, geranylacetone and $\beta$-ionone with boiling points between 228 and $239^{\circ} \mathrm{C}$ and molecular weights between 190 and $194 \mathrm{amu}$,
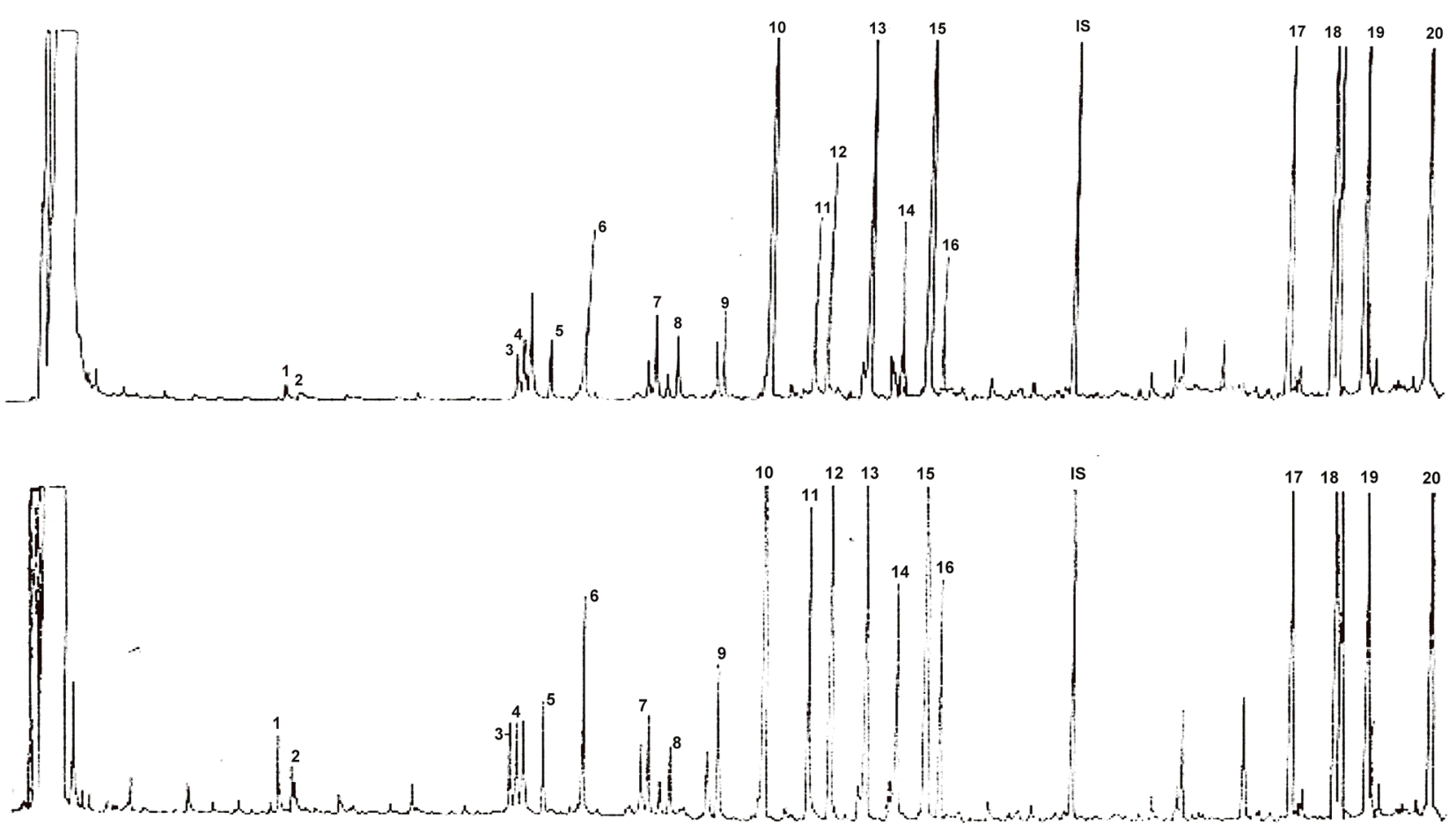

Figure 3. Gas chromatograms of the flavor constituents in mainstream smoke of (a) $70 \%$ and (b) $0 \%$ filter ventilation cigarette samples. 1 = Methylpyrazine; 2 = Furaldehyde; $3=5$-Methylfuraldehyde; 4 = Benzaldehyde; $5=6$-Methyl-5-hepten-2-one; $6=$ Trimethylpyrazine; $7=2$-Acetylpyridine; $8=$ Phenylacetaldehyde; $9=$ Acetophenone; $10=$ Linalool; $11=\beta$-Phenylethyl alcohol; $12=$ Isophorone; $13=$ Oxoisophorone; $14=$ Benzyl acetate; $15=$ Menthol; $16=$ Ethyl octanoate; $17=\beta$-Damascenone; $18=\beta$-Damascone; 19 $=$ Geranylacetone; $20=\beta$-Ionone; IS = Phenylethyl acetate. 
Table 3. The deliveries and the reduction of flavor constituents at different filter ventilation levels

\begin{tabular}{|c|c|c|c|c|c|c|c|c|c|c|c|c|}
\hline \multirow[b]{2}{*}{ Compound } & \multicolumn{2}{|c|}{$0 \%$ ventilation } & \multicolumn{2}{|c|}{$10 \%$ ventilation } & \multicolumn{2}{|c|}{$30 \%$ ventilation } & \multicolumn{2}{|c|}{$50 \%$ ventilation } & \multicolumn{2}{|c|}{$70 \%$ ventilation } & \multirow[b]{2}{*}{$\begin{array}{c}\text { B.P. } \\
{ }^{\circ} \mathrm{C}\end{array}$} & \multirow[b]{2}{*}{$\begin{array}{l}\text { Mol. } \\
\text { wt. }\end{array}$} \\
\hline & $\begin{array}{l}\text { Delivery } \\
\mu \mathrm{g} / \mathrm{cig}\end{array}$ & A.Q. ${ }^{a}$ & $\begin{array}{c}\text { Delivery } \\
\mu \mathrm{g} / \mathrm{cig}\end{array}$ & $\begin{array}{c}\text { Reduction } \\
\%^{b}\end{array}$ & $\begin{array}{c}\text { Delivery } \\
\mu \mathrm{g} / \mathrm{cig}\end{array}$ & $\begin{array}{c}\text { Reduction } \\
\%\end{array}$ & $\begin{array}{c}\text { Delivery } \\
\mu \mathrm{g} / \mathrm{cig}\end{array}$ & $\begin{array}{c}\text { Reduction } \\
\%\end{array}$ & $\begin{array}{c}\text { Delivery } \\
\mu \mathrm{g} / \mathrm{cig}\end{array}$ & $\begin{array}{c}\text { Reduction } \\
\%\end{array}$ & & \\
\hline Methylpyrazine & 19.60 & 5 & 16.56 & 16 & 11.75 & 40 & 5.73 & 71 & 2.34 & 88 & 135 & 94 \\
\hline Furaldehyde & 17.67 & 4 & 15.80 & 11 & 11.58 & 34 & 8.56 & 52 & 3.10 & 82 & 161 & 96 \\
\hline 5-Methylfuraldehyde & 29.64 & 7 & 28.06 & 5 & 22.96 & 23 & 19.20 & 35 & 7.42 & 75 & 187 & 110 \\
\hline Benzaldehyde & 17.88 & 4 & 15.95 & 11 & 12.06 & 33 & 8.21 & 54 & 4.28 & 76 & 179 & 106 \\
\hline $\begin{array}{l}\text { 6-Methyl-5-hepten-2- } \\
\text { one }\end{array}$ & 20.99 & 5 & 16.32 & 22 & 7.57 & 64 & 6.64 & 68 & 3.55 & 83 & 173 & 126 \\
\hline Trimethylpyrazine & 41.83 & 10 & 36.23 & 13 & 26.04 & 38 & 17.78 & 57 & 12.26 & 71 & 172 & 122 \\
\hline 2-Acetylpyridine & 29.12 & 7 & 26.73 & 8 & 21.39 & 27 & 15.86 & 46 & 8.31 & 71 & 192 & 121 \\
\hline Phenylacetaldehyde & 17.28 & 4 & 16.81 & 3 & 15.06 & 13 & 9.97 & 42 & 3.69 & 79 & 195 & 120 \\
\hline Acetophenone & 27.64 & 7 & 24.87 & 10 & 18.66 & 32 & 16.17 & 41 & 9.09 & 67 & 201 & 120 \\
\hline Linalool & 70.46 & 18 & 66.56 & 6 & 58.68 & 17 & 49.61 & 30 & 40.88 & 42 & 198 & 154 \\
\hline$\beta$-Phenylethyl alcohol & 91.98 & 23 & 86.69 & 6 & 76.11 & 17 & 65.53 & 29 & 54.95 & 40 & 220 & 122 \\
\hline Isophorone & 72.25 & 18 & 69.15 & 4 & 62.52 & 13 & 49.80 & 31 & 38.83 & 46 & 213 & 138 \\
\hline Oxoisophorone & 63.85 & 16 & 61.88 & 3 & 57.38 & 10 & 45.24 & 29 & 35.28 & 45 & 211 & 152 \\
\hline Benzyl actate & 42.01 & 11 & 39.31 & 6 & 33.77 & 20 & 26.34 & 37 & 19.45 & 54 & 215 & 150 \\
\hline Menthol & 136.60 & 34 & 132.80 & 3 & 124.3 & 9 & 105.00 & 23 & 88.83 & 35 & 216 & 156 \\
\hline Ethyl octanoate & 33.24 & 8 & 30.58 & 8 & 25.21 & 24 & 19.91 & 40 & 14.44 & 57 & 207 & 172 \\
\hline$\beta$-Damascenone & 83.11 & 21 & 81.45 & 2 & 75.00 & 10 & 70.61 & 15 & 53.22 & 36 & 228 & 190 \\
\hline$\beta$-Damascone & 88.96 & 22 & 87.47 & 2 & 81.26 & 9 & 75.28 & 15 & 57.02 & 36 & 232 & 192 \\
\hline Geranylacetone & 79.62 & 20 & 78.95 & 1 & 74.44 & 7 & 68.19 & 14 & 50.99 & 36 & 238 & 194 \\
\hline$\beta$-lonone & 83.99 & 21 & 82.39 & 2 & 76.89 & 8 & 69.63 & 17 & 54.71 & 35 & 239 & 192 \\
\hline
\end{tabular}

${ }^{a}$ A.Q.: compared to the injected amount, $400 \mu \mathrm{g} / \mathrm{cig}$ (the delivery of 0 filter ventilation/400).

${ }^{\mathrm{b}}$ Compared to the unvented cigarette smoke.

Table 4. The deliveries and the reduction of routine smoke components at different filter ventilation levels

\begin{tabular}{|c|c|c|c|c|c|c|}
\hline Smoke components & Filter ventilation & $0 \%$ & $10 \%$ & $30 \%$ & $50 \%$ & $70 \%$ \\
\hline \multirow[t]{2}{*}{$\mathrm{CO}$} & Delivery, mg/cig & 14.2 & 12.9 & 10.3 & 6.4 & 2.6 \\
\hline & Reduction, \% & 0 & 9.2 & 27.5 & 54.9 & 81.6 \\
\hline \multirow[t]{2}{*}{ 'Tar' } & Delivery, mg/cig & 15.0 & 13.4 & 12.0 & 7.6 & 3.0 \\
\hline & Reduction, \% & 0 & 10.7 & 20.0 & 49.3 & 80.0 \\
\hline \multirow[t]{2}{*}{ TPM } & Delivery, mg/cig & 19.00 & 17.32 & 15.79 & 10.42 & 5.53 \\
\hline & Reduction, \% & 0 & 8.8 & 16.9 & 45.2 & 70.9 \\
\hline \multirow[t]{2}{*}{ Nicotine } & Delivery, mg/cig & 1.20 & 1.15 & 1.03 & 0.79 & 0.49 \\
\hline & Reduction, \% & 0 & 4.1 & 14.2 & 34.2 & 59.2 \\
\hline \multirow[t]{2}{*}{ Water } & Delivery, mg/cig & 2.82 & 2.80 & 2.74 & 2.05 & 2.00 \\
\hline & Reduction, \% & 0 & 0.7 & 2.8 & 27.3 & 29.1 \\
\hline
\end{tabular}

show reductions from 1 to $2 \%$ at $10 \%$ ventilation and from 35 to $36 \%$ at $70 \%$ ventilation. Because of the small differences in their boiling points and molecular weights among these four substances, their deliveries are similar.

The deliveries of the flavor constituents may also be related to molecular structure and polarity. For instance, phenylacetaldehyde and acetophenone have similar boiling points and their molecular weights are identical; their reductions are $79 \%$ and $67 \%$ respectively, at $70 \%$ ventilation. However phenylethyl alcohol and $\beta$-damascenone have similar boiling points but significantly different molecular weights and their reduction with changing ventilation is similar. This indicates that boiling point has greater effect on delivery than does molecular weight. E.g., ethyl octanoate has a greater molecular weight and lower boiling point than $\beta$-phenylethyl alcohol, isophorone, oxoisophorone, benzyl acetate and menthol, yet the delivery of ethyl octanoate is less and, the reduction with ventilation is greater.
The effects of filter ventilation on the deliveries of routine smoke constituents

Table 4 shows the deliveries and the reduction of TPM, nicotine, 'tar', carbon monoxide and water in cigarette mainstream smoke at the five cigarette ventilation levels. In Table 4, we see that all these components are decreased with increasing dilution but they are decreased in different proportions. $\mathrm{CO}$ is reduced more than the other routine components.

\section{The effects of filter ventilation on sensory quality}

The result of sensory evaluations is shown in Table 5 . Cigarette sensory quality includes taste and aroma. The evaluation panel comparison shows that when the filter is ventilated, the smoke is diluted. Not only are the taste, aroma and physiological strength weakened but also the 


\begin{tabular}{|c|c|c|c|c|c|c|}
\hline Filter ventilation & Quality of aroma & Volume of aroma & $\begin{array}{l}\text { Physiological } \\
\text { strength }\end{array}$ & Irritancy & Offensive odor & After taste \\
\hline 0 & moderate & rich & moderate & $\mathrm{a} \mathrm{bit}^{+}$ & a bit & $\operatorname{cozy}^{+}$ \\
\hline $10 \%$ & moderate & rich $^{-}$ & moderate & $\mathrm{a} \mathrm{bit}^{-}$ & a bit & cozy \\
\hline $30 \%$ & moderate $^{-}$ & a bit & moderate & $\mathrm{a} \mathrm{bit}^{-}$ & a bit $^{-}$ & $\mathrm{cozy}^{-}$ \\
\hline $50 \%$ & moderate ${ }^{-}$ & a bit $^{-}$ & weak $^{+}$ & $\mathrm{a} \mathrm{bit}^{-}$ & a bit $^{-}$ & $\operatorname{cozy}^{-}$ \\
\hline $70 \%$ & moderate $^{-}$ & poor & weak & nothing & a bit $^{-}$ & $\mathrm{cozy}^{-}$ \\
\hline
\end{tabular}

quality of aroma, the offensive odor, irritation and aftertaste are changed slightly. These sensory evaluations are consistent with the analytical results.

\section{CONCLUSION}

It is clear from the foregoing discussion that the deliveries of aroma constituents, TPM, nicotine, 'tar', carbon monoxide and water in cigarette mainstream smoke decrease with increased filter ventilation. Therefore, when low- 'tar' cigarettes are made through the use of ventilation technology, different constituents and their changes should be taken into account in order to determine appropriate leaf group blending and flavoring.

\section{ACKNOWLEDGMENT}

This study was supported by a grant from the China National Tobacco Company.

\section{REFERENCES}

1. Rowland, R.L.: Flue-cured tobacco. Neophytadiene; J. Am. Chem. Soc. 79 (1957) 5007-5010.

2. Rowland, R.L., and J.A.Giles: Flue-cured tobacco. Polyisoprenoid compounds; Tob. Sci. 4 (1960) 29-32.

3. Stedman, R.L: Turkish tobacco substitute; U.S. Patent 3,180, 340 (April 27, 1965).

4. Stedman, R.L: The chemical composition of tobacco and tobacco smoke; Chem. Rev. 68 (1968) 153-207.

5. Kimland, B., A.J. Aasen, and C.R. Enzell: Tobacco chemistry. 12. Neutral volatile constituents of Greek tobacco; Acta. Chem. Scand. 26 (1972) 1281-1284.

6. Kimland, B., A.J. Aasen and C.R. Enzell: Tobacco chemistry. 10. Volatile constituents of Greek tobacco; Acta Chem. Scand. 26 (1972) 2177-2184.

7. Kimland, B., A.J. Aasen, S.O. Almqvist, O.Arpino, and C.R. Enzell: Volatile acids of sun-cured Greek Nicotiana tabacum; Phytochemistry 12 (1973) 835-847.

8. Kimland, B., R.S. Appleton, A.J. Aasen, J. Roeraade, and C.R. Enzell: Neutral oxygen-containing volatile constituents of Greek tobacco; Phytochemistry 11 (1972) 309-316

9. Appleton, R.A., C.R. Enzell, and B. Kimland: Tobacco chemistry. 3: Unsaturated hydrocarbon constitutes of Greek tobacco; Beitr. Tabakforsch. 5 (1970) 266-274.

10. Schumacher, J.N. and L. Vestal: Isolation and identification of some components of Turkish tobacco; Tob. Sci. 18 (1974) 43-48.
11. Chuman, T.: Chemical studies on aroma constituents of Turkish tobacco; Sci. Papers, Cent. Res. Inst. Japan Tobacco \& Salt Public Corp. 119 (1977) 45-92.

12. Chuman, T.: Acidic aroma constituents of Turkish tobacco; Inter. Congr. Essential Oil 7 (1977) 435.

13. Demole, E. and D. Berthet: A chemical study of burley tobacco flavour (Nicotiana tabacum L.). Volatile to medium-volatile constituents; Helv. Chim. Acta 55 (1972) 1866-1882.

14. Demole, E. and D. Berthet: A chemical study of burley tobacco flavour (Nicotiana tabaccum L.). Mediumvolatile, free acidic constituents ( b.p. $84-114{ }^{\circ} \mathrm{C} / 0.001$ Torr); Helv. Chim. Acta 55 (1972) 1898-1910.

15. Roberts, D.L. and W.A. Rohde: Isolation and identification of flavor components of burley tobacco; Tob. Sci. 16 (1972) 107-112.

16. Fujimori, T.: Chemical studies on the aroma constituents in burley tobacco; Sci. Papers, Cent. Res. Inst., Japan Monopoly Corp.118 (1976) 85-119.

17. Fujimori, T., R. Kasuga, H. Kaneko, and M. Noguchi: Neutral volatile components of burley tobacco; Beitr. Tabakforsch. Int. 9 (1978) 317-325.

18. Fujimori, T.: Studies on tobacco aroma; Nippon Nogeikagaku Kaishi 53 (1979) (No.9) R95-R121.

19. Kiefer, J.E.: Ventilation filters and their effect on smoke composition; Rec. Adv. Tob. Sci. 4 (1978) 69-84.

20. Baker, R.R.: The effect of ventilation on cigarette combustion mechanism; Rec. Adv. Tob. Sci. 10 (1984) $88-150$.

21. Norman, V., A.M. Ihrig, R.A. Shoffner, and M.S. Irel: The effect of tip dilution on the filtration efficiency of upstream and downatream segments of cigarette filter; Beitr. Tabakforsch. Int. 12 (1984) 178-185.

22. Parris, M.E., C.N. Harward, and G. Vilcins: Simultaneous monitoring of filter ventilation and a gaseous component in whole cigarette smoke using tunable diode laser infrared spectroscopy; Beitr. Tabakforsch. Int. 13 (1986) 169-181.

23. Schultz, T.H., R.A. Flath, T.R. Mon, S.B. Eggling and R. Teranishi: Isolation of volatile components from model system; J. Agr. Food Chem. 25 (1977) 446-449.

\section{Corresponding author}

Gong Changrong

College of Agronomy,

Henan Agricultural University,

No. 95 Wenhua Road, Zhengzhou 450002, Henan,

P.R.China

E-mail:hngongcr069@sina.com 